\title{
Patryk SZAJ
}

Uniwersytet Pedagogiczny im. Komisji Edukacji Narodowej

w Krakowie

\section{Antropocen i kapitałocen: w poszukiwaniu fuzji horyzontów}

Koncepcja antropocenu, przedstawiona na gruncie geologii w 2000 roku (Crutzen, Stoermer 2000), w ciągu dwóch dekad zrobiła olbrzymią karierę w naukach humanistycznych, inicjując tzw. zwrot geologiczny w ich obrębie (zob. Bonneuil 2015). Od początku towarzyszył jej jednak szereg alternatyw terminologicznych, takich jak kapitałocen, technocen, ekonocen, antrobscen, mizantropocen, mantropocen, nekrocen, plantacjocen, ekocen czy chthulucen. Bodaj najistotniejszą z nich - zarówno pod względem wnikliwości intelektualnej, jak i zakresu oddziaływania - jest propozycja kapitałocenu. Chciałbym prześledzić w niniejszym artykule spór, jaki toczą ze sobą orędownicy obu koncepcji, by na końcu zaproponować fuzję horyzontów obu dyskursów.

\section{Antropocen, czyli najwyższe stadium zielonej arytmetyki}

Zarzuty wobec antropocenu, jakie formułują zwolennicy teorii kapitałocenu m.in. David Ruccio (2011), Tony Weis (2013), Jason W. Moore (2015), Donna J. Haraway (2015), Andreas Malm (2016), Elmar Altvater (2016), Justin McBrien (2016) - zorganizowane są wokół czterech podstawowych tez: 1) antropocen stawia właściwą diagnozę, ale nie oferuje właściwej drogi wyjścia z kryzysu, 2) mówiąc o „antropogenicznych” zmianach klimatu, antropocen ignoruje nierównomierną dystrybucję odpowiedzialności za kryzys klimatyczny i - co 
gorsze - nierównomierne rozłożenie kosztów owego kryzysu pomiędzy krajami globalnej Północy i globalnego Południa, 3) antropocen utrzymuje antropocentryczną, zgoła kartezjańską wizję świata, 4) w konsekwencji: antropocen nie docenia uwikłania gatunku homo sapiens w rozległą sieć życia. Przyjrzyjmy się każdej z tych tez i wspierającym je argumentom.

Najbardziej wpływowy orędownik kapitałocenu, Moore, stwierdza w przedmowie do książki zbiorowej pod swoją redakcją Anthropocene or Capitalocene? Nature, History, and the Crisis of Capitalism, że zwolennicy antropocenu nie potrafią odpowiedzieć na stawiane przez siebie (skądinąd słuszne) pytania. Moore obarcza winą za ten stan rzeczy wciąż żywo oddziałującą w dyskursie antropocenu binarną opozycję Natury i Społeczeństwa ${ }^{1}$. „Argumentacja antropocenu ukazuje dualizm Natura/Społeczeństwo w najwyższym stadium rozwoju"2 (Moore 2016a: 3) - zauważa, że historia ludzkości i historia naturalna splatają się ze sobą, jednak nie rozumie ani „dlaczego”, ani „jak” to się dzieje. Traktując fakty biologiczne i geologiczne jako wystarczającą podstawę dla periodyzacji historycznej, popełnia błąd konsekwencjalizmu, w następstwie czego staje się radykalnym wcieleniem „zielonej arytmetyki”. Moore nazywa tak strategię stosowaną w znacznym spektrum tzw. zielonej myśli, polegającą na dostrzeganiu wpływu działań człowieka na świat pozaludzki przy jednoczesnym zachowaniu zasadniczej niezależności obu porządków - zakłada się tu, że „Historia” stanowi sumę „Społeczeństwa” i jego wpływu na „Naturę”. Dyskurs antropocenu powiela ów schemat, zauważając jedynie, że coś w tym rachunku się nie zgadza - wynik dodawania okazuje się, by tak rzec, ujemny: „Ludzkość, lub Społeczeństwo, lub Kapitalizm plus Natura równa się Katastrofa” (Moore 2016a: 4).

Jeśli jednak pierwszą przesłankę tego myślenia stanowi przekonanie, że konsekwencje ludzkich działań determinują periodyzację (propozycje ustanowienia początku epoki antropocenu w konkretnym momencie historycznym, w którym dałoby się wyznaczyć wiarygodny marker stratygraficzny: od wymiany kolumbijskiej, przez rewolucję przemysłową, po wielkie przyspieszenie po II wojnie światowej), to równie niebezpieczne okazuje się drugie założenie,

1 Moore zapisuje słowa „Society” i „Nature” wielkimi literami, aby podkreślić, że mamy tu do czynienia „realnymi abstrakcjami”, czyli z pewnymi hipostazowanymi konstruktami metafizycznymi, a nie bytami empirycznymi.

2 Tłumaczenia tekstów, o ile nie zaznaczono inaczej, pochodzą od autora artykułu.

3 Na marginesie warto zauważyć, że zielona arytmetyka wydaje się nieodłączna od nowoczesnej konstytucji, o której w książce Nigdy nie byliśmy nowocześni pisał Bruno Latour (2011). 
iż siłą napędową tych procesów jest anthropos. Jak zauważa Eileen Crist, dyskurs antropocenu naturalizuje w ten sposób ludzki wpływ na klimat i neutralizuje alternatywne wizje moralne, intelektualne czy społeczno-polityczne:

Afirmując centralną pozycję człowieka - jako zarówno siły sprawczej, jak i przedmiotu troski - nie pozostawia wiele dyskursywnej przestrzeni dla zakwestionowania dominacji nad biosferą, prezentując zamiast tego techno-naukową racjonalizację owej dominacji i pragmatyczny apel o pogodzenie się z jej istnieniem. [...] Dyskurs antropocenu przyczynia się do ukrywania faktu, że zagarnianie Ziemi przez człowieka jest (jak dotąd) niepoddanym krytycznej analizie wyborem, zaś zarówno w naszej mocy, jak i w naszej naturze jest wycofanie się z niego, o ile tylko skupilibyśmy na nim nasze twórcze, krytyczne spojrzenie (Crist 2016: 25).

Tym samym przechodzimy do zarzutu drugiego: posługując się ogólną kategorią „człowieka”, dyskurs antropocenu zakrywa fakt, że za kryzys ekologiczno-klimatyczny odpowiedzialni są konkretni aktorzy i konkretny system ekonomiczno-polityczny, nie ludzkość jako taka. Fałszywa ontologia nakazująca rozdzielać „Społeczeństwo” i „Naturę” od samego początku, bijącego w „długim XVI wieku” (zob. Braudel 1992), znajduje się na usługach kapitalizmu i jego modus operandi, czyli ideologii „Taniej Natury”.

Termin ten wydaje się kluczowy dla zrozumienia argumentacji zwolenników kapitałocenu, i to z co najmniej trzech powodów. Po pierwsze, wskazuje, że kapitalistyczna strategia akumulacji opiera się na dwojakim dewaluowaniu natury: obniżaniu jej wartości (tak, aby za „naturę” nie trzeba było wiele płacić), a także nadawaniu jej pośledniej rangi etyczno-politycznej (tak, aby „naturę” można było bezkarnie eksploatować). W ten sposób kapitalizm eksternalizuje środowiskowe koszty produkcji, nie biorąc ich pod uwagę w swych kalkulacjach ekonomicznych:

Ponieważ kapitalizm jest systemem napędzanym przez konkurencję w sferze produkcji, [...] musi zawłaszczać coraz większe sfery nieskapitalizowanej natury. Jak od dawna podkreślają ekonomiści ekologiczni, cały system działa tylko dlatego, że kapitał płaci za jeden zestaw kosztów i ciężko pracuje, aby wszystkie pozostałe koszty pozostawały nieuwzględnione. Dotyczy to przede wszystkim kosztów reprodukcji siły roboczej, pożywienia, energii i surowców (Moore 2016b: 92; zob. też Altvater 2016; Patel, Moore 2019). 
Właśnie dlatego, jak z kolei udowadnia Philip Lymbery, gdyby cena hamburgera „mówiła prawdę”, czyli uwzględniała wszystkie eksternalizowane koszty środowiskowe (to znaczy: wszystko, za co odpowiada przemysłowa hodowla zwierząt, od wycinki lasów deszczowych pod monokulturowe uprawy soi czy kukurydzy, przez zatrucie wód gruntowych, po gigantyczną emisję gazów cieplarnianych, zwłaszcza metanu), musiałby on kosztować 100 dolarów (Lymbery, Oakeshott 2015: 255-268).

Po drugie, co nie mniej ważne, „człowieczeństwo” kapitalistycznego anthroposa bynajmniej nie jest zarezerwowane dla wszystkich przedstawicieli gatunku homo sapiens ani nawet dla większości z nich. Zdaniem Moore’a oraz podążających za nim badaczek i badaczy kapitalizm na przestrzeni wieków wpisywał w kategorię Taniej Natury wielu ludzi: rdzennych mieszkańców Ameryki, niewolników afrykańskich, większość wykonujących nieodpłatną pracę domową kobiet, chłopów pańszczyźnianych i tak dalej. Tania Natura nie znajduje się więc (jak chciałaby zielona arytmetyka) jedynie na zewnątrz społeczeństwa. Znajduje się również w nim samym.

Po trzecie wreszcie, ideologia Taniej Natury wskazuje, że kapitalizm jest czymś znacznie rozleglejszym niż zwykły system gospodarczy (czy nawet gospodarczo-polityczny). Okazuje się on - jak to ujmują zwolennicy kapitałocenu w analogii do pojęcia systemów-światów (Wallerstein 2007) - ekologią-światem: czymś więcej-niż-ludzkim, całościową organizacją władzy, kapitału i natury, relacyjnym polem procesów geofizycznych oraz historii społecznej i ekonomicznej (zob. Moore 2017; Moore, Avallone 2019).

Jakie to wszystko ma znaczenie w kontekście debaty antropocenu i kapitałocenu? Stronnicy tego ostatniego wskazują, że współczesny kryzys ekologiczno-klimatyczny równa się wyczerpaniu Taniej Natury: znajdujemy się w momencie, w którym kapitalizmowi „skończyła się” Ziemia. Nie ma już dokąd eksternalizować kosztów produkcji, co więcej, pora spłacić zaciągany od stuleci dług ekologiczny: to, co dotąd pozostawało „niezaksięgowane” (por. Altvater 2016), powraca ze zdwojoną siłą pod postacią katastrofy klimatycznej, szóstego masowego wymierania, dramatycznej utraty bioróżnorodności, ekstremalnych zjawisk pogodowych - słowem, czegoś, co James Lovelock nazwał „zemstą Gai” (Lovelock 2007). Właśnie dlatego Moore et consortes twierdzą, że należałoby mówić nie o „antropogenicznych”, ale o „kapitałogenicznych” zmianach klimatu (Moore 2017: 71).

To jednak nie wszystko. Trzecia i czwarta z wymienionych wcześniej tez przeciw antropocenowi wynikają z krytycznego namysłu nad dokonywaną przezeń konceptualizacją relacji pomiędzy człowiekiem a aktorami nie-ludzkimi. Antropocen często najzwyczajniej traci tych ostatnich z oczu, czego 
symptomatyczną ilustracją jest charakterystyka „granic planetarnych”. Jak stwierdza autor tego pojęcia, Johann Rockström, wyznaczają one „bezpieczną przestrzeń operacyjną dla ludzkości” (zob. Rockström i in. 2009) - tak jakby celem mitygacji katastrofy klimatycznej było jedynie ocalenie homo sapiens, a nie wszystkich aktorów tego świata czy też - szerzej - warunków stabilności planetarnej sprzyjającej całemu życiu w postaci, w jakiej je znamy.

M.in. z powodu tego typu przeoczeń Crist dochodzi do wniosku, że w dyskursie antropocenu dominuje prometejska i nieuchronnie antropocentryczna wizja świata (nawet jeśli jest to antropocentryzm odwrócony o 180 stopni, w którym nemesis Gai potwierdza ludzką hybris), a z zadawanych w jego obrębie pytań, czy ludzie urośli do rangi wielkiej siły geologicznej (por. Steffen, Crutzen, McNeill 2007), wyłania się przewrotna (i zgubna) pochwała ludzkiej sprawczości (Crist 2016). Choć wydaje się, że Crist redukuje dyskurs antropocenu do jednego nurtu zwanego „dobrym antropocenem”, na co wskazywała Ewa Bińczyk (Bińczyk 2018a: 18, na temat dobrego antropocenu zob. Bińczyk 2018b), to jednak coś jest na rzeczy. Nawet Clive Hamilton, którego trudno posądzać o sprzyjanie wulgarnemu ekomodernizmowi, opowiada się za odrzuceniem posthumanizmu jako rewolucji, która wydarzyła się zbyt późno, i za ustanowieniem „nowego antropocentryzmu” oddzielającego ziarno ludzkiej odpowiedzialności od plew przybierających postać mrzonek o wspólnocie więcej-niż-ludzkiej (Hamilton 2017: 36-75). Zwolennicy kapitałocenu odpowiedzieliby na tego typu wezwania, iż nie da się rozwiązać problemu za pomocą środków, które to w pierwszej kolejności do niego doprowadziły. Dlatego proponują oni radykalnie odmienną wizję - za Haraway nazwać ją można wspólnotą sympoietyczną (Haraway 2016), zaś za Moore’em socjalizmem dla wszystkich istot (Moore, Avallone 2019: 21).

\section{Antropocenowe refutacje}

Wydaje się jednak, że krytyka zaproponowana przez orędowników kapitałocenu sama wystawia się na parę krytycznych pytań. Przede wszystkim, jak zauważa Bińczyk, termin „antropocen” z pewnością ma pewne wady, ale jego kapitalną zaletą pozostaje to, że spaja on dyskusje przedstawicieli nauk przyrodniczych i nauk humanistycznych, którzy wcześniej mówili raczej obok siebie niż ze sobą (Bińczyk 2018a: 101-103). Tym samym staje się modelowym wcieleniem tzw. trzeciej kultury, czyli swoistej syntezy humanistyki i przyrodoznawstwa (zob. Brockman, red. 1996; Snow 1999; Fiedorczuk, Baltrán 2020). M.in. z tego powodu nawet zwolennik ekosocjalizmu Ian Angus, autor książki Facing the Anthropocene: Fossil Capitalism and the Crisis of the Earth System oraz blogu 
o wiele mówiącej nazwie Climate \& Capitalism, stwierdza, iż tom zbiorowy pod redakcją Moore’a Anthropocene or Capitalocene? „mija się z celem” (Angus 2016).

$\mathrm{Ci}$, którzy skłonni są pozostać przy kategorii antropocenu, podkreślają, że bynajmniej nie abstrahuje ona od kontekstu ekonomiczno-politycznego. Choćby Will Steffen, Paul Crutzen i John McNeill, badacze często stanowiący obiekt ataku zwolenników kapitałocenu, wyraźnie podkreślają związek wielkiego przyspieszenia (olbrzymiego „postępu” cywilizacyjnego i towarzyszącego mu dramatycznego wzrostu zużycia zasobów, emisji gazów cieplarnianych, urbanizacji, utraty bioróżnorodności oraz nierówności społecznych) z rozwojem kapitalizmu przemysłowego (por. Steffen, Crutzen, McNeill 2007). Hamilton z kolei odnotowuje rolę globalizacji, która zadekretowała ewolucję kapitalizmu przemysłowego w kapitalizm konsumpcyjny (zob. Hamilton 2017). Australijski ekonomista zauważa też, że dyskurs kapitałocenu dokonuje nieuprawnionego (i nieuczciwego) przeniesienia problemu z pola geologii na pole nauk społecznych: z punktu widzenia tej pierwszej nie ma nic kontrowersyjnego $\mathrm{w}$ tezie o hipersprawczości człowieka, jest natomiast coś kontrowersyjnego w umieszczaniu początku nowej epoki geologicznej w XVI wieku, jak to czyni Moore, gdyż nie da się odnaleźć tam żadnego wiarygodnego markera stratygraficznego (Hamilton 2017: 29).

Według Hamiltona propozycja kapitałocenu ignoruje także obliczenia, zgodnie z którymi do 2050 roku emisje krajów globalnego Południa przekroczą emisje krajów rozwiniętych, w związku z czym trudno o wszystko obwiniać najsilniejszych aktorów gospodarczo-politycznych (Hamilton 2017: 30). Co więcej, zdaniem autora Defiant Earth trudno oskarżać system kapitalistyczny jako taki, skoro wielu ludzi z własnej woli przykłada się do jego rozwoju. Akurat te argumenty wydają się jednak nietrafione. Po pierwsze, wcale nie zdejmują odpowiedzialności z systemu kapitalistycznego, ponieważ tzw. kraje rozwijające się w najlepszym razie suwerennie go implementują, w najgorszym zaś - są do tej implementacji zmuszane za pomocą wszelkiego rodzaju „traktatów o wolnym handlu”, a także działalności Międzynarodowego Funduszu Walutowego czy Banku Światowego ${ }^{4}$. Po drugie, Hamilton powiela tu autodefinicję kapitalizmu jako systemu gospodarczego oderwanego od sieci życia, tymczasem cała argumentacja kapitałocenu opiera się na próbie udowodnienia, że kapitalizm właśnie nie jest od tej sieci oderwany: zarówno się na niej opiera (nie byłoby kapitalizmu bez Taniej Natury), jak i aktywnie ją przekształca (Moore 2016a: 4).

4 Pewne wyobrażenie na ten temat dają reportaże popularnonaukowe: Głód Martína Caparrósa (Caparrós 2016) oraz Władcy jedzenia Stefana Libertiego (Liberti 2019). 
Niemniej Hamilton nie pozostaje dłużny krytykom antropocenu i sam parokrotnie przechodzi do ataku. Przede wszystkim traktuje orędowników kapitałocenu (Moore’a, Malma, Alfa Hornborga, Lisę Sideris) jako niewolników modernizmu. Zdaniem autora Requiem for a Species, sytuując się w polu nauk społecznych i sprowadzając kryzys klimatyczny do kwestii „przezwyciężenia” paradygmatu kapitalistycznego, dyskurs kapitałocenu ignoruje fundamentalne rozpoznanie nauki o systemie Ziemi - że mianowicie już doszło do zerwania w obrębie warunków planetarnych, w związku z czym w diagnozie antropocenu nie chodzi bynajmniej o „rosnący” wpływ człowieka na ekosystemy, ale o to, że stabilny, sprzyjający cywilizacjom ludzkim (i życiu, jakie znamy) klimat holocenu stał się przeszłością. Tym, co czai się na horyzoncie, jest radykalna niestabilność i nieprzewidywalność „krnąbrnej Ziemi”, należy więc - mówiąc potocznie - ratować, co się da, a nie bawić się w reformatorów społecznych (Hamilton 2017: 58-66).

W konsekwencji Haraway - bądź co bądź wykwalifikowanej biolożce autor Defiant Earth zarzuca „beztroskie” czy nawet „aroganckie” ignorowanie nauki o systemie Ziemi, a dokonywaną przez Moore’a próbę połączenia „antropocentrycznego marksizmu” i „feministycznego posthumanizmu” określa jako „nieporęczną” (Hamilton 2017: 93-98). Znów jednak można by zapytać, czy Hamilton w ferworze argumentacji nie przeinacza tez swych adwersarzy. Czy rzeczywiście ignorują oni różnicę między geologią a naukami społecznymi? Np. Moore w artykule Anthropocenes and the Capitalocene Alternative mówi o dwóch obiegach dyskursu antropocenu. Pierwszy - geologiczny - jest niebudzącym wątpliwości, użytecznym pojęciem naukowym. Kłopot w tym, że drugi - popularny - dokonuje nieuprawnionego przeniesienia rozpoznań geologicznych na grunt namysłu „nad źródłami i rozwojem nowoczesnego kryzysu ekologicznego” (Moore 2017: 72). Właśnie ów „popularny antropocen” więcej kwestii zaciemnia, niż wyjaśnia, i to z nim polemizuje propozycja kapitałocenu.

Innym autorem, który nie zgadza się z krytyką formułowaną z pozycji „zielonego marksizmu” (Foster 200o; por. Burkett 1999), jest postkolonialny historyk Dipesh Chakrabarty. Wskazuje on na dwie interesujące kwestie. Po pierwsze, nawet jeśli kapitalizm ponosi winę za planetarny kryzys klimatyczny (czego żaden poważny przedstawiciel dyskursu antropocenu nie podważa), to jednak wielkie przyspieszenie wydatnie przyczyniło się też do dekolonizacji oraz egalitaryzacji społeczeństw. Nie stanowi to dla autora Klimatu historii argumentu na rzecz utrzymania systemu kapitalistycznego, ale raczej nierozwiązywalną sprzeczność (Chakrabarty 2015: 52). Po drugie, podobnie jak Hamilton, Chakrabarty stoi na stanowisku, iż narracja o kapitalizmie nie jest wystarczająco szeroką ramą badania zmian klimatu, ponieważ 
obecny kryzys uwidocznił pewne inne warunki istnienia życia w ludzkiej postaci, które nie mają żadnego istotowego związku z logiką kapitalistycznych, nacjonalistycznych czy socjalistycznych tożsamości. Wiążą się raczej z historią życia na tej planecie; sposobem, w jaki odmienne formy życia łączą się ze sobą oraz w jaki masowe wymieranie jednego gatunku może wróżyć zagrożenie innego. Pozbawiony tego rodzaju historii życia kryzys zmiany klimatu nie ma ludzkiego „znaczenia” (Chakrabarty 2014: 193).

Cytat ten dowodzi jednak, że również Chakrabarty przeinacza stanowisko orędowników kapitałocenu. Znów trzeba powtórzyć, że tym ostatnim nie idzie o kapitalizm rozumiany jako system gospodarczy, ale o kapitalistyczną ekologię-świat - całościową organizację relacji między kapitałem, ludźmi oraz aktorami pozaludzkimi. Dlatego właśnie zdaniem Moore’a kapitalizmu nie można ograniczyć do ery paliw kopalnych, ale należy poszukiwać jego źródeł już w XVI wieku, w czasach pierwotnej akumulacji kapitału. Dlatego też inny badacz, McBrien, nazywa naszą epokę „nekrocenem”: kapitalizm ma bowiem w sobie coś z „nekrofila” (opiera się na ekstrakcji martwego życia: paliw kopalnych) i, zwrotnie, sam prowadzi do „nekrozy”: szóstego masowego wymierania (zob. McBrien 2016). Co więcej, zasadnie byłoby zapytać, czy społeczeństwa planetarne rzeczywiście zegalitaryzowały się tak bardzo, jak chciałby Chakrabarty. Czy nie jest tak, że po dekolonizacji politycznej nastąpiła neokolonizacja gospodarcza? Czy nierówności - zarówno pomiędzy globalną Północą a globalnym Południem, jak i w obrębie poszczególnych państw - nie stają się coraz większe i coraz bardziej niesprawiedliwe?

Wydaje się zatem, że stawką w sporze kapitałocenu $\mathrm{z}$ antropocenem jest coś innego niż zwykłe odnotowanie sprawczej roli kapitalizmu w planetarnym kryzysie ekologiczno-klimatycznym. Orędownicy kapitałocenu zwracają uwagę na to, że dyskurs „popularnego” antropocenu nie bierze na serio możliwości zmiany ontologicznej: zmiany relacji między człowiekiem a resztą biosfery. Próżno np. szukać propozycji takiego przewartościowania wśród wymienianych przez Steffena, Crutzena i McNeilla scenariuszy zarządzania kryzysem klimatycznym (badacze ci wyliczają trzy możliwe filozofie działania: pogłębiające katastrofę business as usual; łagodzenie skutków, głównie za pomocą rozwiązań technologicznych; opcje geoinżynieryjne) (por. Steffen, Crutzen, McNeill 2007: 619-620). Podobnie rzecz się ma u Hamiltona: nie stawia on na ontologię ludzkości-w-obrębie-sieci-życia, lecz na ontologię ludzkiej-wyjątkowości-w-obrębie-sieci-życia (Hamilton 2017: 100). 
Właśnie dlatego Hornborg stwierdza, że przezwyciężenie charakterystycznego dla antropocenu ludzkiego gatunkowizmu (por. Singer 2018) opierać się musi na odnotowaniu dwóch kwestii:

(1) bodźce, korzyści i negatywne następstwa uprzemysłowienia są bardzo nierównomiernie rozłożone pomiędzy grupy społeczne w obrębie gatunku ludzkiego; (2) nie ma nic biologicznie nieuniknionego w instytucjach i formach organizacji społecznej, które znamy jako kapitalizm (Hornborg 2015: 62).

\section{W stronę fuzji horyzontów}

Z jednej strony trudno nie odnieść wrażenia, że antropocenowo-kapitałocenowa wymiana argumentów mija się z celem - nie dlatego, że jest nieistotna, ale dlatego, że mamy tu do czynienia nie tyle $\mathrm{z}$ dialogiem w obrębie jednego paradygmatu, ile z konfliktem różnych paradygmatów. Podczas gdy antropocen wdraża geologiczne skale czasoprzestrzenne, mówi o hipersprawczości gatunku ludzkiego i nierzadko pozostaje perspektywą antropocentryczną, kapitałocen odwołuje się do historycznego (nie geohistorycznego) długiego trwania, obarcza odpowiedzialnością za kryzys klimatyczny konkretnych aktorów gospodarczych i zwraca się przeciw dualizmowi Społeczeństwo/Natura.

$\mathrm{Z}$ drugiej strony w obu propozycjach chodzi z grubsza o to samo: o uniknięcie najczarniejszego scenariusza oraz o zminimalizowanie nieuniknionych skutków kryzysu ekologiczno-klimatycznego. Na obie też spojrzeć można jako na specyficzną pracę rozumienia polegającą na próbie właściwego zdiagnozowania „momentu dziejowego”, w jakim znalazła się ludzkość, a wraz z nią cała sieć życia, oraz sformułowania adekwatnych odpowiedzi na ów stan rzeczy. Właśnie na tym zdaniem Hansa-Georga Gadamera polega świadomość hermeneutyczna:

Efektywnodziejowa świadomość stanowi [...] pewien moment uzyskiwania zrozumienia i [...] jest efektywna już w dochodzeniu do trafnego pytania. Efektywnodziejowa świadomość jest przede wszystkim świadomością hermeneutycznej sytuacji. Uzyskanie świadomości pewnej sytuacji jest jednak w każdym przypadku zadaniem o swoistym stopniu trudności. Pojęcie sytuacji oznacza przecież, że nie znajdujemy się na zewnątrz niej i dlatego nie możemy mieć o niej żadnej przedmiotowej wiedzy (Gadamer 2004: 414; por. Szaj 2021). 
Jeśli przystaniemy na tę charakterystykę, okaże się, że dyskursy antropocenu i kapitałocenu stawiają tezę hermeneutyczną: kondycja ludzka, a wraz z nią kondycja całego świata pozaludzkiego, uległa fundamentalnemu przeobrażeniu - nastąpiła „systemowa zmiana” warunków planetarnych (Moore 2016a: 1), Ziemia wkroczyła w fazę terra incognito (por. Steffen, Crutzen, McNeill 2007: 614), to, z czym się mierzymy, nie jest zwykłą eskalacją kryzysu klimatycznego, ale zerwaniem (Hamilton 2017: 1-5), rozdarciem metabolicznym (Foster 2000). „Nieznane”, w jakie wchodzimy, stanowi więc radykalne wyzwanie dla rozumienia, któremu nie sprostamy, wybierając tylko jedną drogę postępowania czy jedną propozycję dyskursywną - dlatego zasadna wydaje mi się próba fuzji horyzontów antropocenu i kapitałocenu.

Mówiąc bardziej precyzyjnie, uważam, że do takiej fuzji tak czy owak dochodzi, rzecz w tym, by ją sobie uzmysłowić i twórczo wykorzystać. Wbrew pozorom fuzja taka nie byłaby wcieleniem heglowskiej dialektyki, czyli syntezą tezy i antytezy: „Zadanie hermeneutyczne polega na tym, by tego napięcia nie zakrywać przez jego naiwną niwelację, lecz je świadomie rozwijać” (Gadamer 2004: 420). Fuzja horyzontów to tak naprawdę wypracowywanie wspólnego języka, wspólnej „rzeczy rozumienia” - nie chodzi tu o jakiś rzeczywisty punkt dojścia, ale o swoistą ideę regulatywną, wskazującą na to, że dialog nigdy się nie kończy, a raz stopione horyzonty bardzo szybko na nowo się poróżniają. Oznaczałoby to, że trzeba iść dwiema ścieżkami naraz: przyjąć odpowiedzialność za hipersprawczość gatunku ludzkiego (jak np. w propozycji „nowego antropocentryzmu” Hamiltona), ale też uzmysłowić sobie strukturalne przyczyny owej hipersprawczości (ustanowienie kapitalistycznej ekologii-świata) i radykalnie zmienić dotychczasowe przesądy ontologiczne traktujące człowieka jako wyróżniony byt (czyli spojrzeć na koncepcje posthumanistyczne przychylniej niż Hamilton).

W takim ujęciu koncept kapitałocenu byłby raczej implikacją dyskursu antropocenu, czymś weń wpisanym, a nie jego przeciwieństwem. Tezę tę potwierdza kilka argumentów. Po pierwsze, marksowska kategoria rozdarcia metabolicznego, czyli radykalnej sprzeczności pomiędzy logiką kapitalizmu a wyznaczającymi "granice wzrostu” (zob. Meadows i in. 1973) prawami biologii, jest przywoływana przez zwolenników obu koncepcji. Chętnie operuje nią Moore, natomiast na gruncie antropocenu odwołuje się do niej choćby Jean-Baptiste Fressoz (Fressoz 2015: 78). Po drugie, obie koncepcje podważają ontologię oddzielającą „człowieka” od „natury”. Dla Moore’a pojęcia te są albo realnymi abstrakcjami znajdującymi się na usługach ideologii Taniej Natury, albo składnikami zielonej arytmetyki, którą należałoby zdekonstruować. Jak wskazuje Hamilton, taką samą dekonstrukcję wymuszają na nas ustalenia klimatologii: 
Współczesna klimatologia mówi nam, że nowoczesny podział świata na pudełko z napisem „Natura” i pudełko z napisem „Człowiek” jest już nie do utrzymania. W systemie klimatycznym to, co naturalne, i to, co ludzkie, zostaje ze sobą wymieszane, a nie po prostu do siebie dodane, a wpływu jednego na drugie nie da się dokładnie rozróżnić (Hamilton 2015: 34).

Po trzecie wreszcie, sam Moore przyznaje, iż antropocen jest epoką geologiczną, w której żyjemy, ale tym, co poprzedzało kryzys klimatyczny, a co dziś go napędza, jest kapitałocen. Autor Capitalism in the Web of Life nie ma te $\dot{z}$ wątpliwości, że antropocen będzie trwał dużo dłużej niż kapitałocen, tzn. że skutki relatywnie krótkiej epoki kapitału rozciągną się na geologiczne długie trwanie (Moore 2017: 73).

Dlatego redaktorzy tomu The Anthropocene and the Global Environmental Crisis stwierdzają, że „polityka antropocenu” powinna przybrać bardziej marksowski charakter i traktować Ziemię jako pełnoprawny podmiot polityczny (Hamilton, Bonneuil, Gemenne 2015: 9-12). Dlatego Chakrabarty podkreśla konieczność łączenia namysłu nad historią planetarną z krytyką kapitalizmu (Chakrabarty 2014: 189; por. Emmet, Lekan, red. 2016). Dlatego Haraway obstaje przy potrzebie więcej niż jednej narracji, więcej niż jednej nazwy, wchodzących ze sobą w dialog i odzwierciedlających więcej-niż-ludzki świat (Haraway 2015: 16o). Kryzys klimatyczny woła o nową transdyscyplinarność, a nawet o postdyscyplinarność - nie da się już uprawiać geologii, a obok niej socjologii, trzeba rozwijać wielonurtowy i wielowymiarowy namysł nad „końcem świata, jaki znamy” (por. Leggewie, Welzer 2012). Stąd też leciwa kategoria fuzji horyzontów wydaje mi się tu na miejscu. Moment dziejowy, w jakim się znaleźliśmy, z całą mocą potwierdza bowiem prawdziwość słów Gadamera, iż „zły to hermeneuta, który sobie wyobraża, że może lub musi mieć ostatnie słowo” (Gadamer 2004: 757). Zła to refleksja nad katastrofą klimatyczną, której się wydaje, że to do niej powinno należeć ostatnie zdanie. 


\section{| Bibliografia}

Altvater Elmar (2016), The Capitalocene, or, Geoengineering against Capitalism's Planetary Boundaries, w: Anthropocene or Capitalocene? Nature, History, and the Crisis of Capitalism, red. Jason W. Moore, PM Press, Oakland, s. 138-152. Angus Ian (2016), 'Anthropocene or Capitalocene?' misses the point, Climate and Capitalism, https://tinyurl.com/25wruspm [dostęp: 7.01.2021].

Bińczyk Ewa (2018a), Epoka człowieka. Retoryka i marazm antropocenu, PWN, Warszawa.

Bińczyk Ewa (2018b), Idea wspaniałego antropocenu: wrogie przejęcie czy antropodycea?, „Prace Kulturoznawcze”, nr 1-2, s. 31-44.

Bonneuil Christophe (2015), The Geological Turn: Narratives of the Anthropocene, w: The Anthropocene and the Global Environmental Crisis: Rethinking Modernity in a New Epoch, red. Clive Hamilton, Christophe Bonneuil, François Gemenne, Routledge, New York, s. 17-31.

Braudel Fernand (1992), Kultura materialna, gospodarka i kapitalizm XV-XVIII wiek, t. 1-3, przeł. Maryna Ochab, Piotr Graff, PIW, Warszawa.

Brockman John, red. (1996), Trzecia kultura, przeł. Piotr Amsterdamski, CiS, Warszawa.

Burkett Paul (1999), Marx and Nature: A Red and Green Perspective, Palgrave Macmillan, New York.

Caparrós Martín (2016), Głód, przeł. Marta Szafrańska-Brandt, Wydawnictwo Literackie, Kraków.

Chakrabarty Dipesh (2014), Klimat historii. Cztery tezy, „Teksty Drugie”, nr 5, s. $168-199$.

Chakrabarty Dipesh (2015), The Anthropocene and the Convergence of Histories, w: The Anthropocene and the Global Environmental Crisis: Rethinking Modernity in a New Epoch, red. Clive Hamilton, Christophe Bonneuil, François Gemenne, Routledge, New York, s. 44-56.

Crist Eileen (2016), On the Poverty of Our Nomenclature, w: Anthropocene or Capitalocene? Nature, History, and the Crisis of Capitalism, red. Jason W. Moore, PM Press, Oakland, s. 14-33.

Crutzen Paul, Stoermer Eugene (2000), The Anthropocene, „IGBP Global Change Newsletter", t. 41, s. 17-18.

Emmet Robert, Lekan Thomas, red. (2016), Whose Anthropocene?, „Transformations in Environment and Society", nr 2.

Fiedorczuk Julia, Baltrán Gerardo (2020), Poza trzecią kulturę, w: ciż, Ekopoetyka. Ekologiczna obrona poezji, Muzeum Historii Polskiego Ruchu Ludowego, Uniwersytet Warszawski, Warszawa, s. 25-35.

Foster John Bellamy (2000), Marx’s Ecology, Monthly Review Press, New York. 
Fressoz Jean-Baptiste (2015), Losing the Earth Knowingly: Six Environmental Grammars around 180o, w: The Anthropocene and the Global Environmental Crisis: Rethinking Modernity in a New Epoch, red. Clive Hamilton, Christophe Bonneuil, François Gemenne, Routledge, New York, s. 70-83.

Gadamer Hans-Georg (2004), Prawda i metoda. Zarys hermeneutyki filozoficznej, przeł. Bogdan Baran, PWN, Warszawa.

Hamilton Clive (2015), Human Destiny in the Anthropocene, w: The Anthropocene and the Global Environmental Crisis: Rethinking Modernity in a New Epoch, red. Clive Hamilton, Christophe Bonneuil, François Gemenne, Routledge, New York, s. 32-43.

Hamilton Clive, Bonneuil Christophe, Gemenne François (2015), Thinking the Anthropocene, w: The Anthropocene and the Global Environmental Crisis: Rethinking Modernity in a New Epoch, red. Clive Hamilton, Christophe Bonneuil, François Gemenne, Routledge, New York, s. 1-13.

Hamilton Clive (2017), Defiant Earth. The Fate of the Humans in the Anthropocene, Allen\&Unwin, Crows Nest.

Haraway Donna (2015), Anthropocene, Capitalocene, Plantationocene, Chthulucene: Making Kin, „Environmental Humanities”, nr 1, s. 159-165.

Haraway Donna (2016), Staying with the Trouble: Anthropocene, Capitalocene, Chthulucene, w: Anthropocene or Capitalocene? Nature, History, and the Crisis of Capitalism, red. Jason W. Moore, PM Press, Oakland, s. 34-76.

Hornborg Alf (2015), Uncovering ecologically unequal exchange in the world-system, w: The Anthropocene and the Global Environmental Crisis: Rethinking Modernity in a New Epoch, red. Clive Hamilton, Christophe Bonneuil, François Gemenne, Routledge, New York 2015, s. 57-69.

Latour Bruno (2011), Nigdy nie byliśmy nowocześni. Studium z antropologii symetrycznej, przeł. Maciej Gdula, Oficyna Naukowa, Warszawa.

Leggewie Claus, Welzer Harald (2012), Koniec świata, jaki znaliśmy. Klimat, przyszłość i szanse demokracji, przeł. Piotr Buras, Krytyka Polityczna, Warszawa.

Liberti Stefano (2019), Władcy jedzenia. Jak przemysł spożywczy niszczy planete, przeł. Ewa Nicewicz-Staszowska, Agora, Warszawa.

Lovelock James (2007), The Revenge of Gaia. Earth's Climate Crisis and the Fate of Humanity, Penguin, New York.

Lymbery Philip, Oakeshott Isabel (2015), Farmagedon. Rzeczywisty koszt taniego mięsa, przeł. Ryszard Oślizło, Vivante, Białystok.

Malm Andreas (2016), Fossil Capital: The Rise of Steam Power and the Roots of Global Warming, Verso, London.

McBrien Justin (2016), Accumulating Extinction: Planetary Catastrophism in the Necrocene, w: Anthropocene or Capitalocene? Nature, History, and the Crisis of Capitalism, red. Jason W. Moore, PM Press, Oakland, s. 116-137. 
Meadows Donella i in. (1973), Granice wzrostu, Państwowe Wydawnictwo Ekonomiczne, Warszawa.

Moore Jason W. (2015), Capitalism in the Web of Life: Ecology and the Accumulation of Capital, Verso, London.

Moore Jason W. (2016a), Introduction: Anthropocene or Capitalocene? Nature, History and the Crisis of Capitalism, w: Anthropocene or Capitalocene? Nature, History, and the Crisis of Capitalism, red. Jason W. Moore, PM Press, Oakland, s. 1-13.

Moore Jason W. (2016b), The Rise of Cheap Nature, w: Anthropocene or Capitalocene? Nature, History, and the Crisis of Capitalism, red. Jason W. Moore, PM Press, Oakland, s. 78-115.

Moore Jason W. (2017), Anthropocenes \& the Capitalocene Alternative, „Azimuth”, t. 9, s. 71-79.

Moore Jason W., Avallone Gennaro (2019), World-Ecology: A Global Conversation, „Sociologia urbana e rurale”, nr 120, s. 9-21.

Patel Raj, Moore Jason W. (2019), Tania natura, przeł. Przemysław Czapliński, Andrzej W. Nowak, w: O jeden las za daleko. Demokracja, kapitalizm i nieposłuszeństwo ekologiczne w Polsce, red. Przemysław Czapliński, Joanna B. Bednarek, Dawid Gostyński, Książka i Prasa, Warszawa, s. 311-331.

Rockström Johan i in. (2009), Planetary Boundaries: Exploring the Safe Operating Space for Humanity, „Ecology and Society”, nr 2, https://tinyurl.com/mtnzbpva [dostęp: 07.01.2021].

Ruccio David (2011), Anthropocene - or How the World Was Remade by Capitalism, https://tinyurl.com/ab26vjud [dostęp: 07.01.2021].

Singer Peter (2018), Wyzwolenie zwierząt, przeł. Anna Alichniewicz, Anna Szczęsna, Marginesy, Warszawa.

Snow Charles P. (1999), Dwie kultury, przeł. Tomasz Baszniak, Prószyński i S-ka, Warszawa.

Steffen Will, Crutzen Paul, McNeill John (2007), The Anthropocene: Are Humans Now Overwhelming the Great Forces of Nature?, „Ambio”, nr 8, s. 614-621.

Szaj Patryk (2021), Hermeneutics at the Time of the Anthropocene: The Case of Hans-Georg Gadamer, „Environmental Values”, nr 2, s. 235-254.

Wallerstein Immanuel (2007), Analiza systemów-światów. Wprowadzenie, przeł. Katarzyna Gawlicz, Marcin Starnawski, Wydawnictwo Akademickie Dialog, Warszawa.

Weis Tony (2013), The Ecological Hoofprint: The Global Burden of Industrial Livestock, Zed Books, London-New York. 


\section{| Abstrakt \\ PATRYK SzAJ \\ Antropocen i kapitałocen: w poszukiwaniu fuzji horyzontów}

Artykuł włącza się w dyskusję pomiędzy koncepcjami antropocenu i kapitałocenu. Rozpoczyna go rekonstrukcja zarzutów, jakie pierwszej z nich stawiają m.in. Jason W. Moore, Eileen Crist czy Donna Haraway (niewłaściwa diagnoza przyczyn kryzysu ekologiczno-klimatycznego, ignorowanie nierównej odpowiedzialności za ów kryzys, utrzymywanie antropocentrycznej wizji świata). Następnie autor przedstawia kontrargumenty zwolenników antropocenu, m.in. Iana Angusa, Clive’a Hamiltona, Dipesha Chakrabarty'ego (antropocen nie ignoruje kontekstu gospodarczo-politycznego, zwolennicy kapitałocenu dokonują nieuprawnionego przeniesienia diagnoz geologicznych na pole socjologii, narracja o kapitalizmie nie jest wystarczająco szeroką ramą badania zmian klimatu). Zakończenie artykułu stanowi próbę fuzji horyzontów obu koncepcji. Autor postrzega je jako dwie wersje hermeneutyki klimatycznej, podejmujące próbę zrozumienia, co dzieje się z naszym światem, i wypracowania odpowiedzi na ów proces.

Słowa kluczowe: antropocen, kapitałocen, kryzys klimatyczny, hermeneutyka, Jason W. Moore, Clive Hamilton

\section{| Abstract}

\section{Patryk Szaj}

\section{Anthropocene and Capitalocene: In Search of a Fusion of Horizons}

The article joins the discussion between the Anthropocene and the Capitalocene. It begins with a reconstruction of the objections to the first one made by, among others, Jason W. Moore, Eileen Crist or Donna Haraway (incorrect diagnosis of the causes of the ecological and climate crisis, ignoring the unequal responsibility for this crisis, maintaining the anthropocentric vision of the world). Subsequently, the author presents counterarguments of the supporters of the Anthropocene, including Ian Angus, Clive Hamilton, and Dipesh Chakrabarty (the Anthropocene does not ignore the economic and political context, supporters of the Capitalocene make an unjustified transfer of geological diagnoses to the field of sociology, the narrative about capitalism is not a broad enough framework to study climate change). The end of the article attempts to fuse the horizons of both concepts. The author sees 
them as two versions of climate hermeneutics, attempting to understand what is happening to our world and to work out an answer to this process.

Keywords: Anthropocene, Capitalocene, climate crisis, hermeneutics, Jason W. Moore, Clive Hamilton

\section{| Biogram}

Patryk Szaj - dr, literaturoznawca, pracownik Uniwersytetu Pedagogicznego im. Komisji Edukacji Narodowej w Krakowie. Autor książki Wierność trudności. Hermeneutyka radykalna Johna D. Caputo a poezja Aleksandra Wata, Tadeusza Różewicza i Stanisława Barańczaka (2019). Redaktor serii Humanistyka Środowiskowa w Wydawnictwie WBPiCAK w Poznaniu. Najbliższe plany naukowe wiąże z zagadnieniami z zakresu ekokrytyki, animal studies i dyskursu antropocenu. W 2021 roku ukaże się jego książka eseistyczna pod roboczym tytułem Pamiętnik z końca świata (jaki znamy).

E-mail: patryk.szaj@up.krakow.pl

ORCID: 0ooo-0002-6315-3317 